\author{
Ewa Szatan \\ Uniwersytet Gdański \\ wnses@ug.edu.pl
}

\title{
Co dzieci myślą o muzyce? Interpretacja muzycznych i literackich treści utworu Sanctus w wypowiedziach dzieci
}

\section{Summary \\ What do children think about music? Interpretation of the musical and literary content of the Sanctus composition in children's speeches \\ Words are unambiguous and it allows the meaning of phenomena to be defined. Music has many meanings, but words are needed so that music can be described. Children can describe the world in which they live, interpret phenomena. As a researcher I wanted to see how children talk about music as they describe what they hear in it. Text is the result of talking with children about music.}

Słowa kluczowe: muzyka, piosenka, dzieci, znaczenia

Keywords: music, song, children, interpretation

\section{Wstęp}

Codzienne wyrażamy zdanie w wielu kwestiach, opiniujemy i oceniamy. Jednak rzadziej dzielimy się swoim spostrzeżeniami związanymi ze sztuką, w tym ze sztuką muzyczną. Wielość słów wypowiadanych przy tym o muzyce nie zawsze oznacza, że ma ono znaczenie dla niej samej. Niemiecki kompozytor okresu romantyzmu Feliks Mendelssohn-Bartholdy, dyrygent, a także interpretator muzyki fortepianowej snuł refleksję, że wiele wypowiada się myśli o muzyce, o jej treściach, o przeżyciach, których muzyka jest źródłem $^{1}$. Zwracał uwagę na fakt, że wyraża się opinie o muzyce, ale werbalizowanie muzyki jest niedoskonałe i nie oddaje tego wszystkiego, co jest zawarte w samej kompozycji, w dźwiękach (Szatan 2016). Myśl ta, pełna powątpiewania (Czy słowami można wyrazić muzykę i jak to czynić? A może pozostawiać ją w sferze intymnych przeżyć?) powstała w XIX wieku pod wpływem rozmów kompozytora z osobami dorosłymi. Czy zatem teraz dwa wieki później nadal zastanawiamy się, jak mówić o muzyce? Skoro to takie trudne, czy można pytać o to dzieci? Słuchając kompozycji muzycznych, czy to dorosły, czy dziecko, profesjonalista czy amator, muzyk, krytyk muzyczny, czy przeciętny słuchacz -

\footnotetext{
1 „Tak wiele mówi się o muzyce, a tak mało w końcu zostaje powiedziane”. Słowa te zostały zapisane w materiałach F. Mendelssohna-Bartholdy'ego, Briefe aus den Jahren 1833 bis 1847, 1864, s. 337-338. W: K. Guczalski (2002), Znaczenie muzyki. Znaczenia w muzyce. Kraków, Musica Jagellonica, s. 211-212.
} 
każdy słucha muzyki inaczej (Koblewska-Wróblowa 1958, Natanson 1978, Tatarkiewicz 1951, Posłuszna 2014).

Ta odmienność słuchania związana jest między innymi z doświadczeniami zdobytymi w zakresie dostrzegania struktury dzieła $\mathrm{i}$ tego wszystkiego, co kompozytor zapisał w partyturze utworu. Znaczenie ma upodobanie i gust muzyczny. Czy bez przygotowania muzycznego dziecko może wypowiadać się o muzyce?

Muzyka jest obecna w świecie dziecka, dlatego odciska ona na nim swoje piętno. Dziecko może nie zauważać lub może nie podejmować próby werbalizowania tego, co jest dla niego oczywiste, jednak zapytane, przypisuje muzyce znaczenia. Opowiada o muzyce swoim językiem, raz uboższym, innym razem wzbogaconym o terminologie muzyczną ${ }^{2}$. Kryterium wieku i osobiste doświadczenie muzyczne sprzyjają odmiennej percepcji muzyki. Może to być świadomy jej odbiór, a czasami tylko jej mimowolne słuchanie. Dziecko, tak jak dorosły człowiek, podejmuje próbę opowiadania muzyki, jej interpretacji, nadawania jej znaczeń, a w odpowiednio kierowanej przez dorosłego rozmowie ocenia ją, poddaje dziecięcej krytyce. Przedmiotem nadawania znaczeń może stać się sam utwór lub konkretne wykonanie kompozycji.

\section{Wypowiadanie się dziecka o muzyce - nadawanie jej znaczeń}

Podążając za wcześniej przywołanymi w tym tekście słowami Feliksa Mendelssohna-Bartholdy'ego (por. przyp. 1), można skonstatować, że ludzie o muzyce wypowiadają wiele słów, ale nie wszystkie nadają jej znaczenia, nie wyjaśniają jej samej. Czasami powściągliwość w werbalizowaniu muzyki może być wartością, o czym czytamy w innym fragmencie wypowiedzi kompozytora: „W ogóle uważam, że słowa nie nadają się do tego celu" (Mendelssohn-Bartholdy 1864: 211). Muzyka ma służyć przede wszystkim do słuchania i przeżywania, ma budzić u odbiorcy określone emocje. Dlatego z jednej strony muzyka ma tak wiele znaczeń, gdyż obywa się „bez słów”3, same dźwięki wyrażają wiele i każdy może użyć do ich „odczytania” własnego kodu i w takim do niej podejściu - muzyka nie jest jednoznaczna. Z drugiej strony właśnie przez mówienie o muzyce wydaje się, że zachodzi u słuchacza głębsza nad nią refleksja. Fakt ten nie może przesłonić prawdziwego przeżywania muzyki (dużej formy muzycznej czy tylko prostej piosenki) - indywidualnego, niezakłóconego żadną sugestią zewnętrzną. Muzyka bowiem jest w samym założeniu abstrakcyjna, jest wieloznaczna. Należy do pozawerbalnych form ekspresji i sztuki ${ }^{4}$, co czyni ją przystępną bez względu na to, jakim językiem werbalnym posługuje się odbiorca-słuchacz, czy jest to dorosły czy jeszcze dziecko. Owa przystępność utworu muzycznego sprawia, że dziecko potencjalnie nie

\footnotetext{
2 Dziecko, które jest uczestnikiem życia muzycznego dorosłych lub odebrało już jakąś cząstkę edukacji muzycznej czy też kształci się muzycznie, może posługiwać się właściwą terminologią muzyczną.

3 Jak w cyklu utworów fortepianowych pt. Pieśni bez słów F. Mendelssohna-Bartholdy’ego.

${ }^{4}$ Oczywiście z pominięciem tekstu, który może być integralną częścią przekazu muzycznego, np. w dziele operowym czy piosence
} 
znajduje punktu odniesienia do tego, co może skłaniać do nadawania znaczeń, a tym samym bodźce muzyczne nie pobudzają umysłu do tworzenia symboli (Wilber 2000). Jak powiada M. Przychodzińska (1984), słowa przekazują dziecku znaczenia, gdyż mowa jest semantyczna, a muzyka, jako właśnie ta forma abstrakcyjna, wypełniająca przestrzeń tylko w czasie rzeczywistym, w czasie wykonywania utworu, jest zdecydowanie asemantyczna. Dziecko słuchając muzyki wokalnej (małych form wokalnych - piosenek), zauważa treści literackie, a dopiero później skupia uwagę na muzycznych ${ }^{5}$. To słowa, jako pierwszoplanowe w piosence, dziecko chce zrozumieć, interpretować, nadawać im znaczenia. Jednakże każdy utwór muzyczny, czy to wokalny czy instrumentalny, to tekst - tekst muzyczny wyrażający formę utworu, jego metrorytmikę i melodię, harmonię, dynamikę, agogikę oraz artykulację. Jest to jednoznaczny konstrukt składniowy muzyki. I w takim rozumieniu jednoznaczne dla każdego dziecka-słuchacza może być odczytanie muzyki, której elementy stanowią integralną całość, ekspresyjną i niepowtarzalną ${ }^{6}$, a jednak nastrój wydobyty z dźwięków o określonym konstrukcie powoduje wieloznaczność muzyki, indywidualną dla każdego dziecka.

Przy założeniu, że znaczeń muzyki nie da się wyrazić dokładnie, można przyjąć, że dziecko dysponuje wystarczającym zasobem słownictwa, które pozwoli mu wypowiadać się o muzyce tej, którą na swoim poziomie percepcji odbiera i przeżywa. Podejmowane próby zwerbalizowania muzyki będą wynikiem rozwoju i związanych z tym cech osobowościowych, jak uzdolnienia muzyczne czy zdolności komunikacyjne i lingwistyczne. Czasami jednak dziecko nie potrafi muzyki „opowiedzieć”, nie potrafi zwerbalizować swoich emocji, które pojawiają się podczas słuchania utworów i wówczas może ono skorzystać z innego sposobu „mówienia” o muzyce - posługiwania się ruchem, gestem (Szatan 2006). Dzieje się tak dlatego, że muzyka nie imituje rzeczywistości, a pobudza wyobraźnię dziecka, które chcąc znaleźć ujście dla emocji, włącza inny kod - ruch interpretatywny, który jest naturalną mową ciała. Jest on uniwersalny i niezależny od wieku wykonawców. Jest włączany przez dzieci do ruchowej opowieści o muzyce. Początkowo jest prymitywny, ale podnosi swoją wartość, gdy na drodze studiów nad ruchem uzyska się umiejętności łączenia porządku w muzyce z ruchliwością, rozmachu interpretacji z opanowaniem, zestawienia z fantazją i temperamentu wykonawcy z charakterem muzyki. Osiąga się to przez studia nad związkami między muzyką a ruchem ciała w gimnastyce rytmicznej Dalcroze'a (Mamontowicz-Łojek 1978). Naturalnym zachowaniem dzieci jest słuchanie muzyki i reagowanie na nią gestami i ruchem, a następnie przy wypowiadaniu się na temat wysłuchanego utworu powracanie do tych reakcji - przypominając sobie ruch, dziecko pomaga sobie w werbalizowaniu muzyki.

\footnotetext{
5 Ta optyka zmienia się, gdy słuchamy muzyki wokalnej z tekstem w języku, którego nie rozumiemy. Wówczas bardziej zauważamy ekspresję muzycznej wypowiedzi i ta ekspresja wyjaśnia nam tekst literacki. I właśnie wtedy sama muzyka ma znaczenie.

${ }^{6}$ Oczywistym jest, że dziecko w wieku przedszkolnym nie będzie potrafiło interpretować wszystkich elementów muzyki, jak np. harmonii w muzyce, ale zapewne ją odczuje.
} 


\section{Percepcja muzyki i dziecięca wyobraźnia}

Dziecko dzięki swoistej dziecięcej wyobraźni potrafi opisywać muzykę i nadawać jej znaczenia. Czyni to w sposób werbalny, jak również awerbalny (ruchowy) (Szatan 2006, Wasilewska 2013). U dzieci młodszych aktywność muzyczna ma znaczenie w percepcji muzyki, a dziecięca wyobraźnia uruchamia się w różnych przejawach tej aktywności, np. w metodzie umuzykalniającej Carla Orffa, w rytmice Emila Jaques-Dalcroze'a czy aktywnym słuchaniu muzyki Batti Strauss. Dlatego w dziecięcym swobodnym muzykowaniu (jak dziecięca improwizowana śpiewanka, wytwór na prostym instrumencie czy komunikat ruchowy) komunikat pozawerbalny powinien być traktowany na równi z werbalnym opisywaniem muzyki, podobnie jak np. w aktywności plastycznej, w której rysunek dziecka może pokazać, co jest dla jego autora ważne w jakiejś sferze życia (Szuman 1990).

Wszystkie komunikaty dziecka mogą mieć podobny wydźwięk. Komunikaty pozawerbalne mogą zawierać elementy ludycznej zabawy, jak i całkiem serio traktowanej twórczości - poprzez nie dziecko wyraża siebie i swoje emocje. W nich estetyka ruchu, wokalnej czy instrumentalnej improwizacji (istotna w wytworze dorosłego), równoważona jest nie zawsze doskonałą u dziecka techniką i dziecięcą ekspresją. Środki muzycznego wyrazu są wynikiem pobudzania wyobraźni dziecka, która uruchamia rozmaite procesy psychiczne i formy dziecięcych zachowań. Można zauważyć u dziecka uruchomienie wyobraźni podczas zabawy muzycznej czy odgrywania „scenek” ruchowych (zadania twórcze w zakresie ruchu), co nawiązuje do badań związków wyobraźni z formami aktywności człowieka (Wasilewska 2013). Formy zachowań dziecka, w których bierze udział wyobraźnia, są dla niego właściwe, mimo że z punktu widzenia osoby dorosłej - nauczyciela czy badacza niektóre z nich mogą nie mieć wymiaru estetycznego. „Nowa sztuka” dziecka powstaje na drodze przekształcania w sposób twórczy zdobytych wcześniej doświadczeń pod wpływem działania wyobraźni. „Wyobraźnia nie stanowi jednak obiektywnego odtworzenia przeszłości, ponieważ cechuje ją swoboda w reprodukcji czegoś dawniej spostrzeganego" (Uszyńska-Jarmoc 2003: 36). Szczególnego znaczenia nabiera wyobraźnia, gdy zmieniają się warunki, np. następuje rozwój umysłowy, rozwija się motoryka dziecka i ogólna sprawność fizyczna i zdolności muzyczne pozwalające na realizację coraz to bardziej zaawansowanych aktów muzycznej

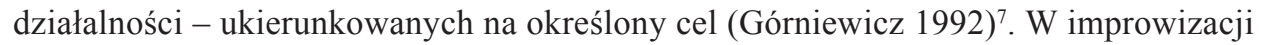
muzycznej (opowiadanie muzyki, nadawanie znaczeń muzyce środkami pozawerbalnymi) to właśnie słuchany konkretny utwór muzyczny, zdolność jego percepcji będą decydowały o uruchomieniu dziecięcej wyobraźni, ale także podobnie jak w wypowiedzi werbalnej - o poziomie „produktywności” i poziomie „oryginalności wyobrażeń” (Wasilewska 2013: 44).

7 To pozwala wg Górniewicza na wyodrębnienie kryteriów opisu dziecięcej wyobraźni. 


\section{Dzieci opowiadają muzykę...}

Wieloznaczność muzyki pozwala na indywidualne nadawanie jej znaczeń, także przez dziecko. Jego opowiadanie muzyki i każde nadane tym samym jej znaczenie, zarazem jest „trafione”, jak i „niewystarczające”. Budzi to zainteresowanie badaczy - między innymi tym, jak dziecko myśli o rzeczywistości, jak ją postrzega, jak ocenia różne zjawiska. Świat muzyki jest cząstką dziecięcego świata, zatem można zapytać, jak ono postrzega muzykę, jak odczytuje utwór muzyczny. To jest problem, który postanowiłam rozwiązać poprzez rozmowę z dziećmi o muzyce, a konkretnie o utworze Sanctus $^{8}$ wykonywanym przez chór chłopięcy Libera9.

Przyjęta przeze mnie strategia badawcza nawiązuje do badań jakościowych A. Clark (2005) i J. Zwiernik (2012). Narracje dzieci stały się dla mnie punktem wyjścia, a poparte aktywnością ruchową nawiązywały do podejścia mozaikowego badaczek. Zauważyłam, że opisywanie muzyki przez dzieci, nadawanie jej znaczeń (ogólnie muzyce, jak i konkretnym utworom) zależą od samej struktury dźwięków, ale także od czynników pozamuzycznych, jak miejsce, w którym słuchają muzyki, do którego przychodzą na „spotkania z muzyką”. Bezpieczne, przyjazne dziecku miejsce daje pole do swobodnej, nieskrepowanej wypowiedzi. Już samo przyzwolenie na wypowiadanie swoich myśli inspirowanych muzyką, dźwiękami było dla uczestniczek rozmowy ciekawym doświadczeniem ${ }^{10}$. Ponieważ wypowiedź werbalna jest naturalnym sposobem wypowiadania się, ale czasami może wystąpić niedostatek odpowiednich słów - uczestnik rozmowy uzupełnia tę wypowiedź swobodnym ruchem - „kodem”, który badacz także poddaje interpretacji. To z kolei wymaga przygotowania i otwartości badacza, np. umiejętności odczytywania niuansów dotyczących wyrażania muzyki ruchem, użycia do tego określonej techniki ruchu i ekspresji, umiejętności odczytania napięć ludzkiego ciała - byłam na to przygotowana (Szatan 2006).

W rozmowach o muzyce uczestniczyło pięć dziewcząt (dwie w wieku 6-7 lat, dwie jedenastolatki i najstarsza miała 14 lat) mieszkających na wsi, uczących się w małym mieście. Na spotkanie wybrałyśmy miejsce dobrze im znane, które lubiły i czuły się w nim swobodnie (spotykałyśmy się tam na zajęciach muzyczno-ruchowych). Razem słuchałyśmy utworu wykonywanego przez chłopięcy zespół wokalny z akompaniamentem instrumentalnym i przyjęłyśmy zasadę, że każda w dowolnej chwili może wypowiadać swoje

\footnotetext{
8 Informacje o utworze i zespole na stronie internetowej: http://www.libera.org.uk/music (dostęp 19.12.2015); http://www.last.fm/pl/music/Libera (dostęp 19.12.2015); Libera Sanctus: https://www. youtube.com/watch? $\mathrm{v}=$ cmuPJvr89Jw (dostęp 16.12.2015).

9 Wersja badań rozszerzona o element ruchu z muzyką - wypowiedzi pozawerbalne dzieci została opisana w: Szatan E. (2016) Jak dzieci wypowiadaja się o muzyce? Interpretacja werbalnych i ruchowych znaczeń nadawanych przez dzieci muzycznym i pozamuzycznym treściom utworu pt. Sanctus (Libera). W: M. Karczmarzyk., A. Lewandowska-Walter, A. Wasilewska (red.), Co dzieci myśla o życiu, religii i sztuce, z cyklu Dziecko a tematy trudne. Gdańsk, Wydawnictwo Harmonia Universalis.

${ }^{10}$ Moje własne doświadczenie zawodowe, jak i obserwacje studentek na moich seminariach magisterskich i licencjackich pokazują, że dzieci w szkole nie mają możliwości wypowiadania się o muzyce. Podobnie było w tym przypadku i dlatego stworzona sytuacja poznawcza była dla dzieci interesującym doświadczeniem, w którym chętnie uczestniczyły.
} 
myśli. Pierwszy raz uczestniczyły w takiej rozmowie, by interpretować muzykę tak jak czują, tak jak ją rozumieją. W szkole uczyły się śpiewać piosenki, więc istotna była tylko znajomość tekstu literackiego, nie nadawanie znaczeń całej kompozycji. Dziewczęta wysłuchały muzyki, a następnie mogły poruszać się w dowolny sposób tak, by ruchem „odczytać” jej treści, by je „dopowiedzieć”, by muzykę jeszcze raz przeżyć i zapamiętać. Muzyczny materiał będący przedmiotem rozmowy to Sanctus - utwór wokalno-instrumentalny, którego pierwowzorem był instrumentalny Kanon D-dur J. Pachelbela ${ }^{11}$. Aranżacja kompozycji na chór chłopięcy zmieniła go poprzez dodanie łacińskiego tekstu i tytułu, który ogólnie nie był zrozumiały dla dziewcząt. Muzyka natomiast po wprowadzeniu zmian w stosunku do wersji oryginalnej Pachelbela zyskała bardziej sakralny charakter i nastrój. Dziewczęta biorące udział w rozmowie nie znały tej kompozycji. Informacje dotyczące tytułu kompozycji, jej autorów, wykonawców zostały przedstawione po zakończonej rozmowie, by uniknąć jakichkolwiek sugestii i skojarzeń. Podczas rozmowy, po „wytańczeniu” muzyki, siedziałyśmy na podłodze. Dziewczęta powtórnie słuchały muzyki w sposób typowy dla dzieci - ich uwaga była skupiona na muzyce, ale żywiołowo reagowały gestami i wypowiadanymi słowami, gdy coś w muzyce je zaskoczyło, zadziwiło. W wypowiedziach wzajemnie się inspirowały, dlatego będę cytowała wypowiedzi bez wskazywania na konkretną osobę

W rozmowie zadawałam pytania i poruszałam się w obszarach tematycznych, które związane były z treściami muzycznymi i pozamuzycznymi utworu, gdyż takie znaczenia nadawały mu moje słuchaczki ${ }^{12}$. Wypowiedzi dziewcząt były zróżnicowane ze względu na ich osobiste doświadczenia. Wykorzystywały swoją wiedzę o muzyce. Słuchając utworu, od razu zwróciły uwagę na wykonawców, na ich wiek i płeć. Porównywały je ze swoimi głosami i kolegów z klasy ${ }^{13}$ :

- To byt chór dziecięcy, bo po głosie było stychać.

- To byty takie dziesięciolatki.

Melodia piosenki miała bardzo duży ambitus ${ }^{14}$, stąd wypowiedzi, że wykonawcy to:

- Dziewczynki, ale tam byt chyba taki chtopczyk jeden, bo to nie byto takie bardzo wysokie.

- Byto caty czas takie wysokie, taki sopran albo taki wysoki bardzo.

- Jak na flecie (i zaśpiewała wysoki dźwięk kojarzony przez nią ze skalą dźwięków instrumentu) albo coś.

- To musiał być któryś z chłopaków, aby to przyniżyć (czyli obniżyć głos, zaśpiewać niższe dźwięki).

\footnotetext{
${ }^{11}$ Albinoni Adagio in G minor / Pachelbel Canon, wykonawca: Berliner Philharmoniker, 1996, płyta CD.

${ }^{12}$ Rozmowa z dziewczętami została przeprowadzona w 2015 roku. Wypowiedzi dzieci o muzyce wykorzystano w publikacji Szatan E. (2016) Jak dzieci wypowiadaja się..., jw.

${ }^{13}$ Wszystkie wypowiedzi mają oryginalne brzmienie.

${ }^{14}$ Ambitus [łac. obwód], rozpiętość interwałowa między najniższym a najwyższym dźwiękiem melodii; np. ambitus melodii w pieśniach ludowych jest zazwyczaj niewielki, uwarunkowany skalą głosu wykonawcy, większy natomiast w muzyce artystycznej, przeznaczonej do wykonywania przez profesjonalnych śpiewaków i instrumentalistów. W: Encyklopedia muzyki PWN (C) Wydawnictwo Naukowe PWN, http:// www.rmfclassic.pl/encyklopedia/ambitus.html (dostęp 27.03.2016).
} 
Czerpiąc z wiedzy osobistej, że kobiety (to znaczy także dziewczynki) mają wyższe głosy a mężczyźni (także chłopcy) - niższe, dokonały porównania słyszanych głosów. Nie znały możliwości śpiewania przez chłopców falsetem, dlatego oceniały wysokie dźwięki melodii jako głosy dziewczęce, a tylko niższe dźwięki przypisywały chłopcom. W wykonaniu zauważyły podział na śpiewający zespół i solistę. Przy tej wypowiedzi najstarsza opisała element dotyczący muzycznej formy utworu: - Melodia się powtarzała - wskazując na powtarzalność tematu muzycznego. Więcej o budowie formalnej utworu nikt już nie mówił.

Uwagę dziewcząt zwrócił język, w jakim śpiewana była piosenka. Od razu zauważyły, że nie mogły opowiedzieć treści piosenki, bo język był dla nich niezrozumiały. Część z nich uczy się języka angielskiego, więc odwołały się do wrażeń słuchowych i pamięci, by ocenić język, w którym śpiewali wykonawcy. Na pytanie: Czy zrozumiałyście stowa, język, w jakim śpiewano? Odpowiadały:

- Ja nie znam tego języka...

- Angielski, chyba nie - włoski. To byt chyba włoski język (jednoczesna wypowiedź trzech osób).

Na dodatkowe pytanie: Czy można się domyśleć, nie rozumiejąc języka, o czym śpiewali wykonawcy? Trzy dziewczęta odpowiedziały chórem:

- O Bogu!

Najstarsza z nich zwróciła uwagę:

- Bo byta ,,gloria”. To byto jak w kolędzie.

Przywołanie kolędy uruchomiło inne skojarzenia - z miejscami w których się śpiewa w takim obcym języku.

- W Rzymie (pierwsza odpowiedź).

Ponownie najstarsza: - Przy papieżu, to znaczy w tej, tej... w bazylice. - (...) u nas także (u nas - czyli w Polsce - przypis autorki). Tak w czasie mszy.

Prawdopodobnie także słowo „gloria” użyte w tekście piosenki wywołało określone skojarzenia. Wyobraźnia została pobudzona osobistymi doświadczeniami - jedna z dziewczynek była w Watykanie i rzeczywiste elementy zostały wplecione w jej wypowiedź. Dziewczęta próbowały nadawać znaczenia słowom wyrażanym w obcym dla nich języku, którego nie potrafiły odczytać wprost, ale czyniły to odwołując się do swojej wiedzy i tworząc sieć skojarzeń. Muzyka, jej nastrój, pomagały w tym, prowadziły w określoną przestrzeń znaczeń.

Muzyka jest wieloznaczna, słowa - nie, ale jeżeli dziecko nie rozumie tekstu piosenki, podejmuje próbę nadawania znaczeń kierując się semantyką samej muzyki. Postawiono dziewczętom pytanie: $O$ czym by opowiadała ta muzyka, gdyby nie było stów? Usłyszałam: - Nie wiem, ale wydaje mi się, że o tagodnej takiej piosence.

To było wskazanie na nastrój utworu, na jego cechy, które dzieci określały, czerpiąc z własnej wyobraźni muzycznej, ale także wiedzy o muzyce.

- Ja nie znam tego języka, na jakimś występie, dzieci sq na biało ubrane na scenie i po prostu śpiewaja. 
W wypowiedziach nastrój muzyki kojarzony jest z kimś, czymś niewinnym, nieskażonym, z białym kolorem, wyobrażającym anioły.

- Wyobrażatam sobie, że można stać i tak wysoko śpiewać (dziewczynka klęka, mimo że proponowała stanie, składa ręce jak do modlitwy i śpiewa improwizowaną melodię na wysokich dźwiękach, odbiegającą od wzoru melodii utworu). W tym momencie inna dziewczynka zainspirowana muzyką mówi:

- Można poruszać się, tylko łagodnie (wstaje, zaczyna poruszać się na palcach i pokazuje rękoma ruch ptasich czy może anielskich(?) skrzydeł. Na jej twarzy pojawia się uśmiech). Jej aktywność innym słuchaczom przywołuje temat aniołów:

- $Z$ aniołkami! (odpowiadają jednocześnie) Tak! Nie! (zdania są podzielone, ale zaraz wyjaśniają:)

- Bo aniotki podobno też tak śpiewaja (wiedza wyniesiona z lekcji religii).

- Tak, ona (muzyka) jest taka jasna i czysta, bo aniołki sa jasne, maja czysty głos.

- Bo one sa na biało ubrane i maja takie (nie potrafi odnaleźć nazwy i pokazuje rękoma nad głową, a starsza podpowiada)...aureole.

- To jest jasne, takie spokojne (składają ręce i przytulają do policzka, jak przy kładzeniu się spać).

Można się zastanowić, czy to nie przejaw synestezji, odczuwanie utworu (tonacji D-dur) w jasnych kolorach, czy tylko stereotyp myślenia, że aniołki mają białe ubrania. Istnieje jeszcze inne wytłumaczenie, że dzieci młodsze odwołują się do świata fikcji, iluzji i mistycyzmu w wypowiedziach. W takim świecie muzyki, której słuchają, wszystko jest dobre, piękne, spokojne, nieskazitelnie czyste, bo łączy się z postaciami aniołów i Boga. Wypowiedzi starszych dziewcząt raczej odwołują się do konkretnej wiedzy i świata mediów, stąd słuchające wycofały się z uwag, by włączyć się po chwili do określania elementów muzyki i pokazania muzyki, występów muzycznych jako formy działań charytatywnych. Wiedzą, że wolontariat i zbiórki na cele charytatywne także są wspierane wykonywaniem muzyki. Przykładem może być doroczna akcja Jerzego Owsiaka - Wielka Orkiestra Świątecznej Pomocy, o której dziewczynki przypomniały, gdyż rozmowa była nagrywana po jej kolejnej edycji.

W następnych wypowiedziach dziewczęta ponownie łączą rzeczywiste doświadczenia z muzyką, wskazują jej funkcje i możliwości wykorzystania dla celów społecznych:

- To mogło być dla jakichś dzieci, które sa chore i to była jakaś zbiórka na przyktad.

- Dzieci śpiewaty z czystościq, śpiewaty tak, jak by chciaty ta zbiórka udowodnić, że to sq czyste zamiary. Albo inaczej - w kościele się coś wydarzyto, np. zapalit się dach i trzeba naprawić dach.

Objaśnianie muzyki przez dzieci czasami bardzo zaskakuje badacza. Tak się stało, gdy jedna z dziewczynek ,anielskie śpiewanie” skojarzyła z momentem umierania i odwołała się do wiary, mówiąc:

- Jak się umiera i idzie do nieba, to można tak śpiewać, tak ,, wooo”, tak w chmurach.

Emocje to kategoria zawsze występująca w rozmowach z dziećmi o muzyce. Muzyka je angażuje, ale uspokaja, jak w tym przypadku: 
- Jak bym chciała namalować obraz o aniołach i stuchałabym takiej muzyki, to mogłabym to zrobić.

- Tak, przy spokojnej piosence to tak trochę idzie malować i przy tej realistyczności to tak... o! Jak by pani np. malowała anioły i stuchała takiej głośnej muzyki, takie bum, bum, bum, to myśle, że pani by nie wyszto to malowanie.

Skonstatować można, że rozmowa z dorosłym o nastrojach, o emocjach, mimo że może być wyzwaniem dla obu stron, jest bardzo dziecku potrzebna. Chce się ono dzielić swoimi radościami, smutkami, sukcesami i niepowodzeniami. Dlatego w tej rozmowie dziewczynki dość swobodnie rozmawiały o tym, co myślą, co czują, bezpiecznie przenosząc to na grunt muzyki. Muzyka stała się pomostem dialogu:

- Jak sa szczęśliwe anioły, to śpiewaja.

- Każda ma swojego anioła stróża, jak anioł za nim idzie do ottarza, do komunii.

Chciałam dopytać: Czy w tej muzyce sq anioły? Dzieci zawołały prawie jednocześnie: Sa, sa!

- Balet lepiej pasuje do tej muzyki (dziewczynka kojarzy ze spokojnymi ruchami ciała).

Ale dodają, że nie każda muzyka, nie każdy utwór „posiada” anioły (ponownie intuicyjnie wskazują na cechy muzyki):

- Nie każda, bo jak jest taka rockowa, rap czy rock, to nie może wyrażać.

Podsumowaniem rozmowy o muzyce było stwierdzenie starszej dziewczynki, która wypowiadając te słowa, subtelnie i z namysłem ściszała głos:

- A ,chóry anielskie” to anioły, jak sa szczęśliwe, to śpiewaja.

Przesłanie tej myśli jest tak proste, jak myślenie dziecka - jesteś szczęśliwy - śpiewasz, żyjesz muzyką.

\section{Zakończenie}

W zabawach dzieci w wieku przedszkolnym i młodszym szkolnym dominuje jeszcze świat fikcji i iluzji. W świat dorosłych dzieci wkraczają zatem z treściami nierealnymi, wymyślonymi, takimi, jakie chcą widzieć i jakich chcą doznawać. U dzieci starszych zauważa się zwiększenie pierwiastka racjonalnego, co jest wynikiem ich dojrzewania i edukacji, ale jednocześnie różne determinanty powodują, że zanika u nich charakterystyczna dla wcześniejszego okresu spontaniczność ${ }^{15}$. Zaobserwować można, że ta fikcja lub przeciwnie, racjonalność, pojawia się w wypowiedziach o muzyce, gdy dzieci nadają znaczenia muzycznym utworom, których słuchają.

Rozmowa z dziećmi o utworze Sanctus ukazała ich otwartość na muzykę. Biorące w niej udział dziewczęta potrafiły mówić z emocjami o fikcyjnych postaciach, jak i odwoływać się do rzeczywistości. Przywoływały obrzędy religijne, znaczenia obiektów

${ }^{15}$ J. Górniewicz w publikacji pt. Rozwój i kształtowanie wyobraźni dziecka. Porady dla rodziców i nauczycieli wskazuje, że dzieci młodsze do ok. 9.-10. roku życia włączane w tryb obowiązków szkolnych i nowe z tym doświadczenia, stają się w działaniach bardziej schematyczne niż w okresie wcześniejszym, co niekorzystnie odbija się także na ich wyobraźni i ekspresji twórczej. 
sakralnych i postaci ważnych dla kościoła, jak postać papieża - przywódcy, na równi z aniołami, postaciami nierealnymi. Przekaz kulturowy o zachowaniu w kościele, wiara w Boga i anioły powodowały ogólne wyciszenie i zmniejszenie dynamiki głosu w ich wypowiedziach (na początku rozmowy dziewczęta były bardzo podekscytowane i mówiły głośniej, bardziej żywiołowo). Świat fikcji łączył się ze światem rzeczywistym. Muzyka, jej nastrój, użyte efekty brzmieniowe głosów ludzkich i instrumentów muzycznych, skala tych głosów, dynamika wywoływały u dziewcząt emocje. Spontaniczność ich wypowiedzi i zachowania zaprzeczają tezie „kryzysu twórczego"16.

Opowiadanie o muzyce, o konkretnym utworze może przebiegać inaczej w różnych warunkach, np. w klasie, w której kolejno „odpytywane” są dzieci, a inaczej poza nią, w licznej grupie lub w małym zespole czy podczas rozmowy indywidualnej. Grupa, z którą rozmawiałam, znajdowała się w przyjaznej dla siebie przestrzeni, w miejscu, do którego przychodziła na zajęcia pozaszkolne, nieprzymuszana przez rodziców. Dzieci nie były dyscyplinowane podczas wypowiedzi, raczej same decydowały o kolejności i przekazie komunikatu werbalnego. O muzyce wypowiadały się językiem starannym, ale mniej formalnym, w przeciwieństwie do reguł obowiązujących w szkole (Klus-Stańska 2002),

w której wymaga się od ucznia używania języka bardzo formalnego. Akceptowano pewne błędy językowe, gdyż dzieci nie zawsze potrafiły użyć terminologii muzycznej, więc tworzyły własne słownictwo. Wypowiadały się w grupie, wzajemnie uzupełniały treści i tak opowiadały pewną historię, nadając muzyce znaczenia. Podejmowały próbę werbalizowania muzyki, która jest abstrakcyjna i działającą na wyobraźnię tylko przez krótki czas trwania utworu, moment trwania dźwięków tworzących ten utwór. Dziewczęta miały zapewnione warunki poznawcze zbliżone do naturalnych (Klus-Stańska 2002) i próbowały wyjaśnić muzykę, używając języka potocznego. Próbowały we właściwy dla siebie sposób tłumaczyć sobie ,świat istniejący obiektywnie” i światu siebie (Ablewicz 1996).

Słuchanie a następnie interpretacja werbalna utworu muzycznego, nadawanie mu znaczeń, to proces twórczy. Twórcze rozwiązywanie problemu, w tym przypadku opis dzieła muzycznego, który może być aktem pojedynczego dziecka, tu był zadaniem grupowym. Każdy odbierał muzykę indywidualnie, lecz potem w zespole, wzajemnie się inspirując, wspólnie tworzono jej opis. Ta praca opierała się na różnorodności dziecięcych pomysłów (Nęcka 1994), jednak w przypadku muzyki szczególnego znaczenia nabierała kwestia zapamiętania utworu jako całości i szczegółów, które wywołują emocje a są warunkiem przeżycia muzyki. Przeżywanie muzyki jest ważnym doświadczeniem człowieka, może zatem należy częściej pytać dzieci Co sobie myśla o muzyce? One tak wiele chcą dorosłym opowiedzieć, ale niestety, zbyt rzadko je o to pytamy (Klus-Stańska 2004).

\footnotetext{
${ }^{16}$ Terminem „kryzys twórczy” określił J. Górniewicz czwarty etap życia dziecka przypadający na przedział wiekowy od 9. do 12. roku życia.
} 


\section{Literatura}

Ablewicz K. (1996), Język potoczny jako warunek dialogu edukacyjnego - w poszukiwaniu języka pedagogiki. „Edukacja. Studia, Badania, Innowacje”, nr 3 (55).

Clark A. (2005), Talking and listening to children. W: M. Dudek (red.), Children's spaces. Oxford, Elsevier.

Górniewicz J. (1992), Rozwój i ksztaltowanie wyobraźni dziecka. Porady dla rodziców i nauczycieli. Warszawa-Toruń, Wydawnictwo Naukowe „Praksis”.

Klus-Stańska D. (2002), Konstruowanie wiedzy w szkole. Olsztyn, Wydawnictwo UWM.

Klus-Stańska D. (2004), Światy dziecięcych znaczeń. Warszawa, Wydawnictwo Akademickie Żak.

Koblewska-Wróblowa J. (1958), Typy przeżyć muzycznych. Zeszyty COPSA, z. 23.

Mamontowicz-Łojek J. (1978), Polskie szkolnictwo baletowe w okresie międzywojennym. Warszawa, PWM.

Mendelssohn-Bartholdy F. (1864), Briefe aus den Jahren 1833 bis 1847. W: K. Guczalski (2002), Znaczenie muzyki. Znaczenia w muzyce. Kraków, Musica Jagellonica.

Natanson T. (1978), Wstęp do nauki o muzykoterapii. Wrocław, Zakład Narodowy im. Ossolińskich - Wydawnictwo.

Nęcka E. (2014), Twórcze rozwiązywanie problemów. Kraków, TROP.

Posłuszna J. (2014), Osobowość a preferencje muzyczne. Lublin, Wydawnictwo UMCS.

Przychodzińska-Kaciczak M. (1984), Zrozumieć muzykę. Warszawa, Nasza Księgarnia.

Szatan E. (2016) Jak dzieci wypowiadaja się o muzyce? Interpretacja werbalnych i ruchowych znaczeń nadawanych przez dzieci muzycznym i pozamuzycznym treściom utworu pt. Sanctus (Libera). W: M. Karczmarzyk., A. Lewandowska-Walter, A. Wasilewska (red.), Co dzieci myśla o życiu, religii i sztuce. Gdańsk, Wydawnictwo Harmonia Universalis.

Szatan E. (2006), Ruch jako komunikacja awerbalna a problem stymulowania aktywności dziecka. W: G. Krasowicz-Kupis (red.), Edukacja a rozwój człowieka. Kraków, Wydawnictwo UJ.

Szuman S. (1990), Sztuka dziecka. Psychologia twórczości rysunkowej dziecka. Warszawa, WSiP.

Tatarkiewicz W. (1951), Skupienie i marzenie, Kraków, Wydawnictwo M. Kot.

Uszyńska-Jarmoc J. (2003), Twórcza aktywność dziecka. Teoria - rzeczywistość - perspektywy rozwoju. Białystok, Wydawnictwo Trans Humana.

Wasilewska A. (2013), Archetypy świata dziecięcego: światy wyobraźni w narracjach dzieci. Gdańsk, Harmonia Universalis.

Wilber K. (2000), Jeden smak. Przemyślenia nad integralna duchowością. Warszawa, Wydawnictwo Jacek Santorski\&CO.

Zwiernik J. (2012), Podejście mozaikowe w badaniu doświadczania przez dzieci życia codziennego w instytucjach wczesnej opieki i edukacji. „Przegląd Badań Edukacyjnych”, nr 2 (15). 